\title{
7-Eleven MELEJIT LEWAT LIFESTYLE
}

\author{
Freddy P. Simbolon \\ Jurusan Manajemen, Fakultas Ekonomi dan Komunikasi, BINUS University \\ Jln. K.H. Syahdan No. 9, Palmerah, Jakarta Barat 11480
}

\begin{abstract}
The landscape of convenient store businesses or minimarkets now have changed. Location base strategy has not been sufficient any longer now. Psychographic and Demographic approaches tend to share a newly built power. Two main variables that have been managers concern at retail level are the store image and the store atmosphere. While the store image dimensions that can be put into considerations are the items offered, services committed, who and the amount of customers, physical facilities, promotion and convenience, store atmosphere, especially the involvement of affections through built emotions status in store which possibly uncautioned wholly by the customers when doing shopping. Since officially opened, the 7-Eleven had offered unique facilities. Instead of providing instant foods and beverages for 24 hours, the 7-Eleven also provides convenient corners and tables to eat and drink and provides chatting facilities for customers who need it. These make other modern retailers following the concept: opened for 24 hours and providing chatting facilities for young people.
\end{abstract}

Keywords: marketing management, consumer behavior, convenient store

\begin{abstract}
ABSTRAK
Landskap bisnis convenience store atau pun minimarket telah berubah. Strategi hanya mengandalkan lokasi sudah tidak lagi memadai. Pendekatan psikografis dan demografi memberikan fungsi lebih menjadi kekuatan baru. Dua variabel utama yang menjadi perhatian manajer pada tingkat eceran adalah citra toko (store image) dan suasana toko (store atmosphere). Dimensi citra toko yang biasa dipelajari adalah barang dagangan, layanan yang diberikan, siapa dan banyaknya pelanggan, fasilitas fisik, promosi dan kenyamanan. suasana toko (store atmosphere) terutama melibatkan afeksi dalam bentuk status emosi dalam toko yang mungkin tidak disadari sepenuhnya oleh konsumen ketika sedang berbelanja. Sejak dibuka, 7-Eleven memang menawarkan fasilitas yang berbeda. Selain menyediakan makanan dan minuman siap saji serta barang kebutuhan sehari-hari selama 24 jam, 7-Eleven juga menyediakan tempat untuk menyantap makanan sekaligus tempat bercengkrama bagi yang membutuhkannya. Ini membuat ritel-ritel modern lain mengikuti konsep toko ini: buka 24 jam dan beberapa di antaranya juga menyediakan tempat bercengkrama bagi pengunjung kawula muda.
\end{abstract}

Kata kunci: manajemen pemasaran, perilaku konsumen, convenience store 


\section{PENDAHULUAN}

Pada masa lalu, pengecer mengamankan loyalitas pelanggan dengan menawarkan lokasi yang nyaman, pilihan barang khusus atau unik, layanan yang lebih banyak atau lebih baik dibandingkan pesaing. Semua ini telah berubah. Jenis toko eceran yang berbeda, seperti toko diskon, toko kelontong (convenience store), pasar swalayan, dan department store telah tumbuh mirip satu dengan yang lain dan semuanya bersaing untuk konsumen yang sama. Selain bersaing lokasi di pusat kota, banyak pengecer mempunyai cabang di pusat belanja pinggiran kota di mana ada tempat parkir yang luas dan meningkatkan fasilitas dan layanan mereka.

Masyarakat juga semakin makmur dan pintar. Pertumbuhan Product Domestic Bruto (PDB) yang mencapai US\$ 3.000 di tahun 2011 berimplikasi kuat pada perubahan perilaku konsumen karena naiknya daya beli masyarakat dan meningkatnya pendidikan. Salah satu trend yang mulai terlihat adalah kebutuhan konsumen yang lebih maju, seperti status sosial, aktualisasi, self-esteem, bersosialisasi, dan berkomunikasi. Di tengah kesibukan mereka, masyarakat urban sering tidak sempat sarapan, makan siang, dan makan malam. Pola penyajian makanan yang praktis dengan harga terjangkau menjadi daya tarik tersendiri. Pertimbangan yang terkait dengan perilaku dan gaya hidup akan sangat mempengaruhi perkembangan ritel modern di masa depan. Semua itu telah ditangkap peluangnya oleh convenience store (ritel modern).

7-Eleven saat ini bisa dikatakan sebagai convenience store yang paling banyak dikunjungi oleh masyarakat dibandingkan dengan Circle k, Alfa Mart, Alfa Midi, dan Indomaret yang sudah lebih dahulu memasuki pasar. Mereka kini tidak lagi mengandalkan pada lokasi yang memadai, namun pendekatan psikografis dan demografis dengan memberikan fungsi lebih menjadi kekuatan baru, yakni suatu toko yang telah berubah fungsinya menjadi kafe pilihan kawula muda sebagai tempat nongkrong.

Bermunculannya gerai-gerai 7-Eleven dalam waktu hampir bersamaan di beberapa sudut kota Jakarta dalam tempo sekitar Januari-Februari 2011 cukup menarik perhatian masyarakat kota metropolitan ini. Lokasi gerai yang berada di posisi strategis, pembangunan yang memakan waktu sangat singkat, kilauan lampu neon yang terang benderang serta kumpulan orang-orang di sitting area menjadi pemandangan khas tiap gerai 7-Eleven.

Penulisan literatur ini bermaksud untuk menyampaikan strategi di balik kesuksesan peritel ini bila ditinjau dari perilaku konsumen. Karena saat ini pelaku bisnis retail harus menggunakan segmentasi multivariabel. Variabel geografis yang selama ini menjadi andalan pelaku bisnis ritel, sudah tidak relevan lagi melainkan dengan cara menambahkan variabel demografis dan psikografis konsumen.

\section{HASIL DAN PEMBAHASAN}

Bila kita ingin melihat hubungan antara perilaku konsumen dan strategi pemasaran pengecer, ada baiknya lebih dulu kita melihat definisi dari segmentasi pasar, penentuan target pasar, dan penetapan posisi pasar. Materi perilaku konsumen, saya ambil referensi buku yang paling sering dipakai di universitas, yaitu karangan Peter dan Olson sebagai analisis strategi pemasaran pengecer pada tahap awal dari perilaku konsumen. Kemudian dua variabel utama perilaku konsumen yakni afeksi dan kognisi menjadi perhatian manajer pada tingkat eceran yang kedua-duanya berkaitan dengan pengaruh ciri-ciri sebuah toko. 


\section{Segmentasi Pasar (Market Segmentation)}

Menurut Kotler dan Keller (2008), segmen pasar terdiri dari kelompok pelanggan yang memiliki seperangkat keinginan yang sama. Tidak ada cara tunggal untuk mensegmentasikan pasar. Pemasar harus mencoba sejumlah variabel segmentasi yang berbeda-beda, sendiri-sendiri atau bersama-sama, dengan harapan dapat menemukan cara terbaik untuk melihat struktur pasar. Lebih lanjut, Kotler dan Keller menyatakan bahwa segmentasi dapat dilakukan berdasarkan variabel-variabel seperti: (1) segmentasi geografis (geographic segmentation). Segmentasi geografis adalah segmentasi yang membagi pasar menjadi unit greografis yang berbeda-beda seperti negara, daerah otonom, kota, atau kawasan pemukiman; (2) segmentasi demografis (demographic segmentation). Segmentasi yang membagi pasar menjadi berbagai kelompok berdasarkan variabel seperti usia, jenis kelamin, siklus hidup keluarga, pendapatan, pekerjaan, pendidikan dan kebangsaan. Faktor-faktor demografis paling sering dipakai sebagai dasar untuk mensegmentasikan kelompok konsumen. Salah satu alasannya adalah kebutuhan, keinginan dan tingkat penggunaan konsumen berhubungan erat dengan variabel demografis. Alasan lainnya adalah bahwa variabel demografis lebih mudah diukur jika dibandingkan dengan jenis variabel lainnya. (3) segmentasi perilaku (behavioral segmentation). Segmentasi ini mengelompokkan pembeli berdasarkan pengetahuan, sikap, tingkat penggunaan atas sebuah produk atau jasa, serta manfaat yang dicari oleh konsumen dalam membeli sebuah produk atau jasa. (4) segmentasi psikografis (psychographic segmentation). Segmentasi ini membagi konsumen menjadi kelompok yang berbeda-beda berdasarkan karakteristik gaya hidup dan kepribadian konsumen.

\section{Penentuan Segmen Pasar (Market Targeting)}

Setelah mengevaluasi berbagai segmen, perusahaan harus memutuskan segmen mana dan berapa segmen yang akan dilayani. Pasar sasaran mencakup seperangkat pembeli yang memiliki kebutuhan atau karakteristik umum yang ingin dilayani oleh perusahaan.

\section{Penetapan Posisi Pasar (Market Positioning)}

Posisi produk adalah cara produk itu didefinisikan oleh konsumen berdasarkan sejumlah atribut tertentu dipikiran konsumen secara relatif terhadap produk-produk yang bersaing. Dengan kata lain, positioning adalah tentang bagaimana suatu merek perusahaan dapat masuk dan menguasai benak pelanggan. Konsumen terlalu banyak dihadapkan dengan informasi tentang produk dan layanan. Konsumen tidak mungkin mengevaluasi ulang produk setiap saat memutuskan pembelian, sebaliknya dalam benak konsumen setiap produk atau merek akan dikelompokkan dalam sejumlah kategori.

Penetapan posisi dimulai dengan produk, yaitu suatu barang, jasa, atau bahkan orang. Penetapan posisi bukanlah kegiatan yang pemasar lakukan terhadap produk, melainkan merupakan kegiatan yang dilakukan pemasar terhadap pikiran calon pelanggan sehingga posisi produk dengan tepat dapat ditanamkan di benak pelanggan. Para pemasar dapat menggunakan 7 atribut penetapan posisi (Kotler, Bowen \& Makens, 2002), yaitu: (1) penetapan posisi berdasarkan atribut produk; (2) penetapan posisi berdasarkan manfaat tertentu yang ditawarkan konsumen; (3) penetapan posisi berdasarkan penggunaannya; (4) penetapan posisi berdasarkan siapa kelompok konsumen yang mungkin menjadi pemakai dari produk atau jasa perusahaan; (5) penetapan posisi berdasarkan pesaing; (6) penetapan posisi berdasarkan kategori produk; (7) penetapan posisi berdasarkan mutu/harga.

\section{Perilaku konsumen}

Dalam bukunya, Consumer Behavior and Marketing Strategy, Peter dan Olson disebutkan bahwa elemen utama dalam kerangka kerja konseptual perilaku konsumen ada empat, yaitu (1) efeksi (affect) dan kognisi (cognition), (2) perilaku (behavior), (3) lingkungan, dan (4) strategi pemasaran (marketing strategy). 


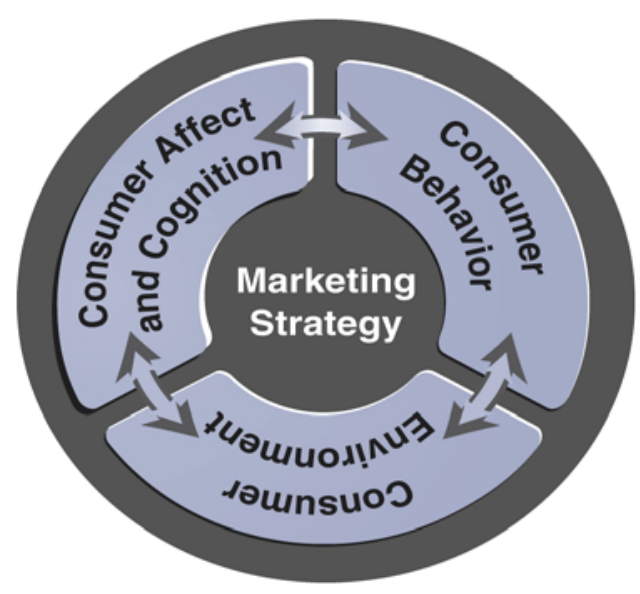

Gambar 1 Roda Analisis Konsumen Sumber: Peter \& Olson (2010)

Keempat elemen tersebut digambarkan dalam satu lingkaran yang mudah untuk dipahami. Elemen efeksi dan kognisi merupakan dua tipe tanggapan internal psikologis pada diri konsumen terhadap rangsangan lingkungan dan kejadian yang berlangsung. Afeksi melibatkan perasaan, sedangkan kognisi melibatkan pikiran. Tanggapan afeksi beragam, misalnya penilaian positif-negatif, rasa senang-tidak senang. Keragaman tanggapan dapat melibatkan emosi (cinta, marah), melibatkan tingkat perasaan (kepuasan, frustasi), dan tergantung pada suasana hati (kebosanan) serta melibatkan evaluasi (suka-tidak suka).

Kognisi merupakan proses mental dan psikologis serta struktur pengetahuan yang dilibatkan dalam tanggapan seseorang terhadap lingkungannya. Hal tersebut termasuk pengetahuan yang didapat dari pengalaman dan pengetahuan yang telah tertanam dalam memori. Proses psikologi yang termasuk dalam aspek kognisi diantaranya perhatian dan pemahaman terhadap aspek lingkungan, mengingat kejadian masa lalu, pembentukan evaluasi, dan pembuatan keputusan pembelian. Aspek kognisi bias terjadi melalui proses berpikir sadar ataupun dapat terjadi secara tidak sadar dan otomatis.

Dalam Peter dan Olson (1999) yang dimaksudkan dengan perilaku (behavior) adalah tindakan nyata konsumen yang dapat diobservasi secara langsung. Afeksi dan kognisi mengacu pada perasaan dan pikiran konsumen, sedangkan perilaku berhubungan dengan apa yang sebenarnya dilakukan oleh konsumen.

Sedangkan yang dimaksud elemen lingkungan (environment) adalah menujuk pada rangsangan fisik dan social yang komplek di luar diri (eksternal) konsumen. Diantaranya adalah benda-benda, tempat dan orang lain yang dapat mempengaruhi efeksi, kognisi serta perilaku konsumen. Adapun yang dimaksud dengan elemen strategi pemasaran dalam kerangka kerja konseptual adalah penempatan rangsangan pemasaran dalam lingkungan. Beberapa rangsangan tersebut adalah produk dan jasa, materi promosi (iklan), tempat penjualan (toko eceran), informasi tentang harga yang ditempel pada produk.

\section{Hubungan antar Elemen}

Secara umum hubungan antar elemen ada dua bentuk, yaitu hubungan satu arah sebab-akibat dan hubungan timbal- balik (Peter dan Olson, 1999). Hubungan sebab-akibat berfokus pada dampak kausal; misalnya hubungan antara kognitif dan perilaku, dampak kausal lingkungan pada perilaku. Bentuk interaksi yang berkesinambungan atau penetapan timbal-balik (reciprocal determinism) menjelaskan hubungan secara simultan dari keseluruhan elemen (efeksi dan kognisi, perilaku, 
lingkungan serta strategi pemasaran). Istilah timbal-balik mengindikasikan aksi saling menguntungkan diantara elemen, dan penetapan mencerminkan dampak yang diakibatkan oleh elemen tersebut.

\section{Afeksi dan Kognisi yang berkaitan dengan toko}

Menurut Peter dan Olson (2010) ada beberapa macam proses afeksi dan kognisi yang dapat didiskusikan jika dikaitkan dengan toko eceran. Akan tetapi, dua variabel utama yang menjadi perhatian manajer pada tingkat eceran adalah citra toko (store image) dan suasana toko (store atmosphere)

Citra toko (store image) dipandang sebagai apa yang dipikirkan konsumen tentang suatu toko. Termasuk di dalamnya adalah persepsi dan sikap yang didasarkan pada sensasi dari rangsangan yang berkaitan dengan toko yang diterima melalui kelima indera. Dalam prakteknya, citra toko biasanya diukur dengan menanyakan konsumen seberapa baik dan seberapa penting berbagai macam aspek dari operasional suatu toko eceran bagi mereka. Dimensi citra toko yang biasa dipelajari adalah barang dagangan, layanan yang diberikan, siapa dan banyaknya pelanggan, fasilitas fisik, promosi dan kenyamanan.

Suasana toko. Dalam bukunya Peter dan Olson, Donovan dan Rossiter menyatakan bahwa suasana toko (store atmosphere) terutama melibatkan afeksi dalam bentuk status emosi dalam toko yang mungkin tidak disadari sepenuhnya oleh konsumen ketika sedang berbelanja. Model dasar yang mendasari penelitian Donovan dan Rossiter ditunjukkan pada gambar berikut ini:

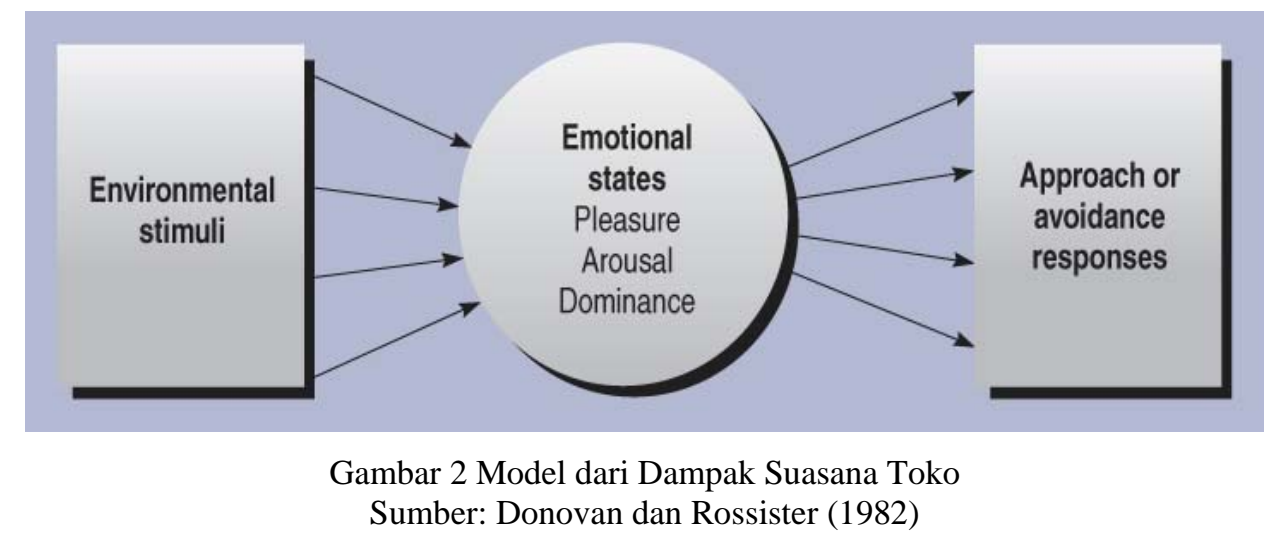

Pengarang tersebut meneliti hubungan antara ketiga status emosi yang ditunjukkan di gambar 3 (senang, bergairah, dan menguasai) dan keinginan yang diungkapkan untuk melakukan perilaku tertentu yang berkaitan dengan toko. Senang (pleasure) mengacu pada sejauh mana konsumen merasa senang, suka cita, atau puas di dalam toko; bergairah mengacu pada sejauh mana konsumen merasa meluap-luap; bergairah (arousal) menngacu pada waspada atau aktif di dalam toko; dan menguasai (dominance) mengacu pada sejauh mana konsumen merasa dikontrol atau bebas berbuat sesuatu dalam toko.

Penelitian Donovan dan Rossiter menemukan bahwa afeksi sederhana, atau kegembiraan yang bersumber dari toko, adalah penentu yang sangat kuat dalam perilaku berbelanja. Selanjutnya, penelitian mereka menyatakan bahwa kegairahan yang bersumber dari toko, dapat meningkatkan lamanya waktu yang diluangkan di dalam toko serta keinginan untuk berinteraksi. Mereka menyatakan bahwa rangsangan dalam toko yang menyebabkan kegairahan antara lain pencahayaan yang terang, dan musik yang mengalun. 
Sementara dimensi emosi ketiga, penguasaan atau sejauh mana konsumen merasa dikontrol atau bebas untuk melakukan sesuatu di dalam toko, terbukti tidak berdampak terlalu banyak pada perilaku konsumen di dalam lingkungan toko pengecer.

\section{Perbedaan antara convenience store dengan minimarket}

Produk yang disediakan oleh convenience store lebih sedikit dibandingkan dengan minimarket, walaupun luas toko pada umumnya hampir sama dengan minimarket. Pelanggan biasanya mendatangi convenience store untuk membeli barang-barang yang segera digunakan. Convenience store juga buka 24 jam 365 hari dalam setahun. Minimarket biasanya tidak buka 24 jam sehari 365 hari setahun, dan barang-barang yang disediakan biasanya untuk dibawa pulang. Banyak perbedaan lain yang terdapat antara convenience store dan minimarket. Jika kebanyakan minimarket memiliki memiliki value harga murah dan menyediakan beragam produk, maka convenience store memaksimalkan kepuasan pelanggan dengan mengutamakan kecepatan layanan, kebersihan, kerapihan toko, keramahan pelayan dan suasana toko yang menyenangkan. Bila ditinjau dari pelanggan, minimarket biasanya didatangi oleh ibu rumah tangga middle low untuk belanja keperluan seminggu, namun convenience store didatangi oleh karyawan dan mahasiswa yang middle up untuk berbelanja kebutuhan saat itu. Karena fungsi dan pelanggan berbeda, pada umumnya desain toko juga berbeda. convenience store memiliki desain modern yang atraktif dengan penawaran ruangan dan cahaya yang diatur dan pengaturan rak dengan tinggi yang cukup agar terkesan luas, sementara minimarket dengan desain standard. Pada intinya, kenyamanan di convenience store menjadi faktor utama.

7-Eleven saat ini bisa dikatakan sebagai convenience store yang paling banyak dikunjungi oleh masyarakat dibandingkan dengan Circle K, AM PM, Alfa Mart dan Indomaret yang sudah lebih dahulu memasuki pasar.

\section{7-Eleven}

7-Eleven adalah jaringan toko kelontong (convenience store) 24 jam asal Amerika Serikat yang sejak tahun 2005 kepemilikannya dipegang Seven \& I Holdings Co., sebuah perusahaan Jepang. Pada tahun 2004, lebih dari 26.000 gerai 7-Eleven tersebar di 18 negara; pasar terbesarnya adalah Amerika Serikat dan Jepang.

Didirikan pada tahun 1927 di Oak Cliff, Texas (kini masuk wilayah Dallas), nama "7-Eleven" mulai digunakan pada tahun 1946. Sebelum toko 24 jam pertama dibuka di Austin, Texas pada tahun 1962, 7-Eleven buka dari jam 7 pagi hingga 11 malam, dan karenanya bernama "7-Eleven" (7Sebelas).

Tahun 1991, Southland Corporation yang merupakan pemilik 7-Eleven, sebagian besar sahamnya dijual kepada perusahaan jaringan supermarket Jepang, Ito-Yokado. Southland Corporation lalu diubah namanya menjadi 7-Eleven, Inc pada tahun 1999. Tahun 2005, seluruh saham 7-Eleven, Inc diambil alih Seven \& I Holdings Co. sehingga perusahaan ini dimiliki sepenuhnya oleh pihak Jepang.

Setiap gerai 7-Eleven menjual berbagai jenis produk, umumnya makanan, minuman, dan majalah. Di berbagai negara, tersedia pula layanan seperti pembayaran tagihan serta penjualan makanan khas daerah. Produk khas 7-Eleven adalah Slurpee, sejenis minuman es dan Big Gulp, minuman soft drink berukuran besar.

7-Eleven di Indonesia dikelola oleh PT Modern Putra Indonesia (MPI) yang membawa jaringan ritel ini ke Indonesia. Anak usaha Grup Modern International, yang juga pemilik lisensi Fuji 
Film di Indonesia, ini memegang hak waralaba 7-Eleven di Indonesia selama 20 tahun dengan masa perpanjangan selama 10 tahun.

Puluhan gerai 7-Eleven di berbagai lokasi di Jakarta dan sekitarnya kini selama 24 jam sehari hampir selalu dipadati pengunjung, baik dari kalangan mahasiswa, pegawai kantor maupun masyarakat sekitar terutama pada jam makan siang. Saat sore sampai malam hari, giliran muda mudi yang memadati gerai.

Sebagai pemain baru, 7-Eleven mencoba pendekatan yang berbeda dibandingkan pemain lain, yakni mengikuti apa yang diinginkan pelanggan dari setiap item di dalam gerai. Contohnya, karena pelanggan menghendaki suasana resto cepat saji yang lebih kental dibandingkan sebuah convenient store, 7-Eleven memutuskan $40 \%$ barang yang dijual adalah dari kategori food and beverage. Sejak dibuka, 7-Eleven memang menawarkan fasilitas berbeda. Selain menyediakan makanan dan minuman siap saji serta barang kebutuhan sehari-hari selama 24 jam, 7-Eleven juga menyediakan tempat untuk menyantap makanan sekaligus tempat bercengkrama bagi yang membutuhkannya. Konsep baru ini direspons antusias oleh konsumen telah mendorong ritel-ritel modern lain mengekornya seperti Alfamart dan Indomaret.

Pengunjung menikmati kenyamanan dan kebebasan yang disediakan oleh 7-Eleven untuk sepuasnya ngobrol sambil makan dan minum, tidak kuatir diusir Satpam atau diantri oleh pengunjung yang lain. Pengunjung merasa bebas dan tidak risih karena diawasi dengan ketat, pihak manajemen cukup memantau dengan kamera CCTV untuk memastikan semua aman dan tidak terjadi pencurian atau hal-hal yang tidak diinginkan.

Pihak 7-Eleven menyediakan tiga tempat untuk konsumen duduk santai menikmati makanan. Konsumen bisa memilih untuk duduk di kursi-kursi yang disediakan langsung di pinggir dekat kasir, atau di luar di pelataran gerai, dan juga tersedia ruang khusus untuk makan di atas yang sekaligus banyak digunakan untuk fasilitas free wi-fi.

Pada dasarnya Toko 7-Eleven menawarkan atau menyediakan produk-produk seperti sabun, pasta gigi, Hot Dog Big Bites seharga Rp 18.000 dan bahkan segelas coffee yang dijual seharga Rp 15.000 dibandingkan dengan Starbuck yang menjual harga Rp 30.000 atau Coffee Bean Rp 40.000. Ini merupakan penetapan harga berdasarkan nilai (value based pricing).

Lama kelamaan gerai 7-Eleven menjadi salah satu tempat favorit untuk anak-anak muda nongkrong, bertemu dengan teman. Hal ini didukung juga dengan jam operasi 7-Eleven yang sebagian besar di buka 24 jam dan 7 hari seminggu nonstop. Apalagi para pengunjung juga bebas untuk dudukduduk tanpa dibatasi waktu. Hal ini cukup menarik, dimana lagi bisa didapatkan tempat bercengkrama tanpa dibatasi waktu, dengan fasilitas internet gratis dan harga makanan yang relatif terjangkau dengan kocek anak muda.

Karena membidik anak muda sebagai target market, 7-Eleven juga menggunakan media sosial sebagai alat pemasarannya. Lewat akun Twitter @7-ElevenID, pihak manajemen menyampaikan program-program pemasarannya. Lewat akun itu juga mereka berinteraksi dengan konsumen sehingga bisa memperoleh insight. 


\section{PENUTUP}

7-Eleven adalah gerai yang telah menjawab kebutuhan anak-anak muda akan gaya hidup modern ala Barat yang identik dengan kebebasan memilih dan berkreasi. Dengan konsep resto, dimana konsumen mengambil dan memilih sendiri makanan yang diinginkan dan meracik minuman sesuai dengan selera masing-masing pribadi, hal ini menjadi daya tarik khususnya bagi kalangan anak muda. Penataan display barang yang dinamis dan terang, sangat "eye catching" dan menarik perhatian pengunjung pada saat melihat barang-barang tersebut. Didukung dengan fasilitas-fasilitas yang disediakan seperti wi-fi, pilihan tempat duduk dan makan, smoking area, ditambah dengan suasana yang nyaman dan kebersihan yang terjamin, maka tidak mengherankan kalau 7-Eleven semakin diminati. Seolah 7-Eleven sudah menjadi bagian dari gaya hidup mereka, menjadi salah satu pilihan tempat favorite untuk sekedar 'nongkrong' dengan teman.

\section{DAFTAR PUSTAKA}

Kotler, P. (2005). Manajemen pemasaran.

Kotler, P., \& Keller, K. (2008). Manajemen pemasaran.

Kotler, P., Bowen, M. (2002). Pemasaran perhotelan dan kepariwisataan.

Peter, P., \& Olson, J. (2010). Consumer behavior. 